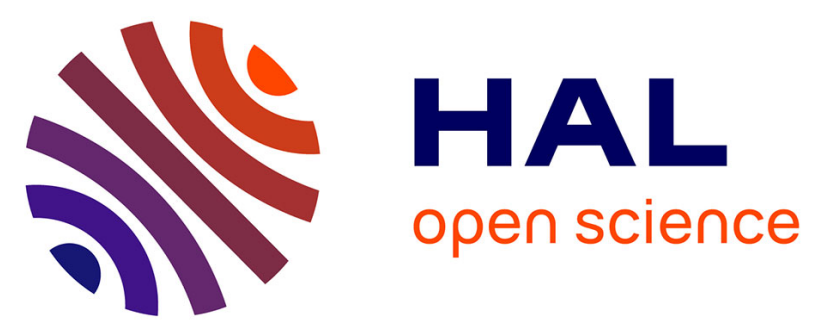

\title{
Dioxygen activation with a cytochrome P450 model. Characterization and electrochemical study of new unsymmetrical tetradentate Schiff-base complexes with iron(III) and cobalt(II)
}

Ali Ourari, Kamel Ouari, Mustayeen A Khan, Gilles Bouet

\section{To cite this version:}

Ali Ourari, Kamel Ouari, Mustayeen A Khan, Gilles Bouet. Dioxygen activation with a cytochrome P450 model. Characterization and electrochemical study of new unsymmetrical tetradentate Schiffbase complexes with iron(III) and cobalt(II). Journal of Coordination Chemistry, 2008, 61 (23), pp.3846-3859. 10.1080/00958970802178257 . hal-03243910

\author{
HAL Id: hal-03243910 \\ https://univ-angers.hal.science/hal-03243910
}

Submitted on 3 Jun 2021

HAL is a multi-disciplinary open access archive for the deposit and dissemination of scientific research documents, whether they are published or not. The documents may come from teaching and research institutions in France or abroad, or from public or private research centers.
L'archive ouverte pluridisciplinaire HAL, est destinée au dépôt et à la diffusion de documents scientifiques de niveau recherche, publiés ou non, émanant des établissements d'enseignement et de recherche français ou étrangers, des laboratoires publics ou privés. 
This article was downloaded by: [Bouet]

On: 21 October 2008

Access details: Access Details: [subscription number 904521677]

Publisher Taylor \& Francis

Informa Ltd Registered in England and Wales Registered Number: 1072954 Registered office: Mortimer House, 37-41 Mortimer Street, London W1T 3JH, UK

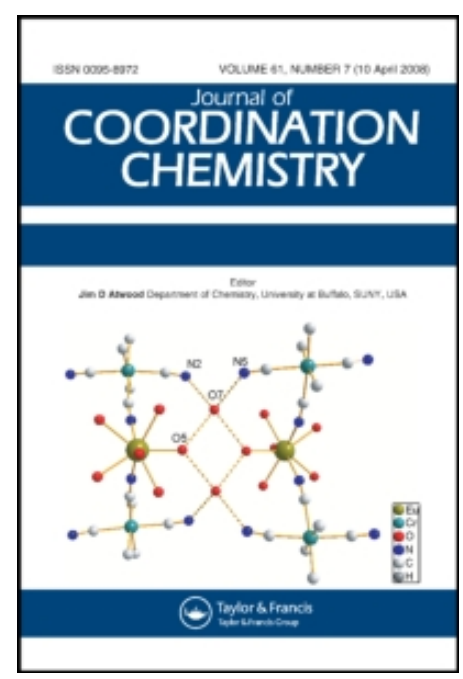

\section{Journal of Coordination Chemistry}

Publication details, including instructions for authors and subscription information:

http://www.informaworld.com/smpp/title content=t713455674

\section{Dioxygen activation with a cytochrome P450 model. Characterization and electrochemical study of new unsymmetrical tetradentate Schiff-base complexes with iron(III) and cobalt(II)}

Ali Ourari a; Kamel Ouari a; Mustayeen A. Khan b; Gilles Bouet ${ }^{b}$

a Laboratoire d'Électrochimie, d'Ingénierie Moléculaire et de Catalyse Rédox (LEIMCR), Faculté des Sciences de l'Ingénieur, Université Ferhat Abbas, Sétif, Algeria ${ }^{\text {b }}$ SONAS, E.A. 921, Faculté de Pharmacie, F-49045 Angers Cedex 01, France

First Published:2008

To cite this Article Ourari, Ali, Ouari, Kamel, Khan, Mustayeen A. and Bouet, Gilles(2008)'Dioxygen activation with a cytochrome P450 model. Characterization and electrochemical study of new unsymmetrical tetradentate Schiff-base complexes with iron(III) and cobalt(II)',Journal of Coordination Chemistry,61:23,3846 - 3859

To link to this Article: DOI: 10.1080/00958970802178257

URL: http://dx.doi.org/10.1080/00958970802178257

\section{PLEASE SCROLL DOWN FOR ARTICLE}

Full terms and conditions of use: http://www.informaworld.com/terms-and-conditions-of-access.pdf

This article may be used for research, teaching and private study purposes. Any substantial or systematic reproduction, re-distribution, re-selling, loan or sub-licensing, systematic supply or distribution in any form to anyone is expressly forbidden.

The publisher does not give any warranty express or implied or make any representation that the contents will be complete or accurate or up to date. The accuracy of any instructions, formulae and drug doses should be independently verified with primary sources. The publisher shall not be liable for any loss, actions, claims, proceedings, demand or costs or damages whatsoever or howsoever caused arising directly or indirectly in connection with or arising out of the use of this material. 


\title{
Dioxygen activation with a cytochrome P450 model. Characterization and electrochemical study of new unsymmetrical tetradentate Schiff-base complexes with iron(III) and cobalt(II)
}

\author{
ALI OURARI $\dagger$, KAMEL OUARI $\dagger$, MUSTAYEEN A. KHAN $\$$ and \\ GILLES BOUET* $*$ \\ †Laboratoire d'Électrochimie, d'Ingénierie Moléculaire et de Catalyse \\ Rédox (LEIMCR), Faculté des Sciences de l'Ingénieur, \\ Université Ferhat Abbas, DZ-19000, Sétif, Algeria \\ †SONAS, E.A. 921, Faculté de Pharmacie, 16 Boulevard Daviers, \\ F-49045 Angers Cedex 01, France
}

(Received 13 June 2007; in final form 3 March 2008)

\begin{abstract}
Salicylaldehyde or 5-bromosalicylaldehyde react with 2,3-diaminophenol to give two unsymmetrical Schiff-bases $\mathrm{H}_{2} \mathrm{~L}^{1}, \mathrm{H}_{2} \mathrm{~L}^{2}$, respectively. With $\mathrm{Fe}(\mathrm{III})$ and $\mathrm{Co}(\mathrm{II})$, these ligands lead to four complexes: $\mathrm{Fe}(\mathrm{III}) \mathrm{ClL}^{1}, \mathrm{Fe}(\mathrm{III}) \mathrm{ClL}^{2}, \mathrm{Co}(\mathrm{II}) \mathrm{L}^{1}, \mathrm{Co}(\mathrm{II}) \mathrm{L}^{2}$. The structures of these complexes were determined by mass spectroscopy, infrared and electronic spectra. Cyclic voltammetry in dimethylformamide (DMF) showed irreversible waves for both ligands. In the same experimental conditions, $\mathrm{Fe}(\mathrm{III}) \mathrm{ClL}^{1}$ exhibited a reversible redox couple $\mathrm{Fe}(\mathrm{III}) / \mathrm{Fe}(\mathrm{II})$ while the three other complexes showed quasi-reversible systems. The behavior of some of these complexes in the presence of dioxygen and the comparison with cytochrome P450 are described.
\end{abstract}

Keywords: Schiff-base; Metal complexes; Dioxygen activation; Cytochrome P450 model; Cyclic voltammetry

\section{Introduction}

The structure, chemistry and metabolic role of cytochrome P450 is well known [1] and its metabolic cycle established [2]. Several steps are involved, molecular dioxygen fixation, water elimination, peroxo high oxidation state metal (i.e. $\mathrm{Fe}^{\mathrm{IV}}$ ) ...; in all cases, the active form of the iron is axially linked to a sulphur protein.

A large number of cytochrome P450 oxo-complexes including ligands such as Schiff-base complexes have been tested for catalytic activity [3-5] and electrocatalytic properties [6-10]. New catalysts derived from unsymmetrical tetradentate Schiff-base complexes seem to be more and more attractive in catalysis [11-13]. These new catalytic or electrocatalytic systems have been less studied than those of symmetrical Schiff-bases.

*Corresponding author. Email: gilles.bouet@univ-angers.fr 
Manganese(III), iron(III), cobalt(II) and copper(II) Schiff-base complexes are used in indirect electroreductions of molecular dioxygen [14-18], carbon dioxide [19] and halohydrocarbons [20-23]. These reactions using electrocatalytic systems could be performed in homogeneous and heterogeneous catalysis. Heterogeneous involves elaboration of modified electrodes (ME) by covalent grafting of pyrrole or thiophene moieties via the etherification reaction of phenol [24]. These materials for electrodes may also be used as amperometric sensors to detect molecular dioxygen [25-27], biomolecules like glucose [28-30] and others [31-33]. Different studies demonstrate the high efficiency of these electrocatalytic systems when operating in a chemicalelectrochemical pathway using modified electrodes based upon organic polymer films containing the complex species covalently grafted as catalyst [17, 31, 32].

We have recently described $\mathrm{Mn}$ (III), $\mathrm{Ni}(\mathrm{II})$ and $\mathrm{Cu}(\mathrm{II})$ complexes with two unsymmetrical Schiff-bases obtained by reacting salicylaldehyde or 5-bromosalicylaldehyde with 2,3-diaminophenol (figure 1) [33]. In the present work, four new complexes with iron(III) and cobalt(II) ions and the two ligands are synthesized and characterized. Our goal was to test these new complexes as cytochrome P450 mimetics, towards dioxygen fixation.

\section{Experimental}

\subsection{Physical measurements}

${ }^{1} \mathrm{H}$ NMR spectra of the ligands were recorded with a Bruker AC 300 at $25^{\circ} \mathrm{C}$ in DMSO-D 6 . All chemical shifts are given in ppm using tetramethylsilane (TMS) as internal reference [33]. The IR spectra were recorded using a Perkin-Elmer 1000-FTIR spectrometer ( $\mathrm{KBr}$ discs). UV-Visible spectra were obtained with a Unicam UV-300 spectrophotometer. The MALDI-TOF spectra, recorded with a Biflex Bruker spectrometer (Ditranol matrix) and the microanalysis were performed on an Elementar-Vario EL III CHNOS at the Institut de Chimie, ULP, Strasbourg University (France). The melting points were determined with a Kofler bench and were uncorrected. Cyclic voltammograms were performed with a Tacussel PJT potentiostat galvanostat, driven by Pilovit-Num. All measurements were done in a $10 \mathrm{~mL}$ Metrohm monocompartment cell equipped with a conventional three-electrode system. The electrodes were polished with diamond paste and rinsed with large amounts of acetone and finally with the solvent. The working electrode was a disc of glassy

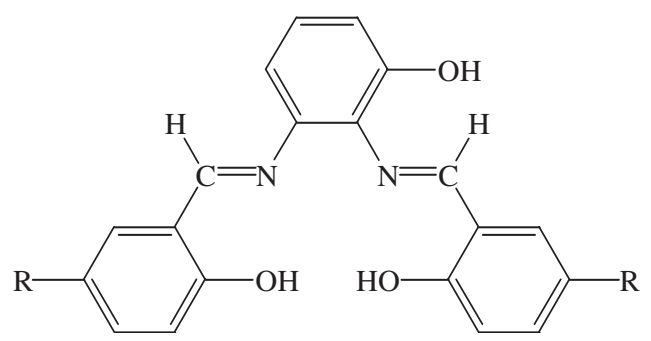

Figure 1. Structure of the ligands: $\mathrm{R}=\mathrm{H}\left(\mathrm{H}_{2} \mathrm{~L}^{1}\right)$ or $\mathrm{Br}\left(\mathrm{H}_{2} \mathrm{~L}^{2}\right)$. 
carbon (3 $\mathrm{mm}$ diameter), the counter electrode a platinum wire and the reference electrode a saturated calomel electrode (SCE). The solvent was DMF with $10^{-3} \mathrm{~mol} \cdot \mathrm{L}^{-1}$ concentration for ligands and complexes, and the ionic strength was maintained at $0.1 \mathrm{~mol} \cdot \mathrm{L}^{-1}$ with $\mathrm{Bu}_{4} \mathrm{NClO}_{4}$ (TBAP).

\subsection{Chemicals}

All chemicals (2,3-diaminophenol, salicylaldehyde, 5-bromosalicylaldehyde, 1-methyl imidazole, benzoic anhydride) and solvents were analytical grade, purchased from Aldrich France and used as received without any further purification. The metals were used as hydrated chlorides.

\subsection{Preparation of the ligands and the complexes}

2.3.1. Ligands. The ligands were obtained and characterized as previously described [33].

2.3.2. Complexes. To a solution of $\mathrm{H}_{2} \mathrm{~L}^{1}$ or $\mathrm{H}_{2} \mathrm{~L}^{2}$ in absolute EtOH $(0.5 \mathrm{mmol}$, $10 \mathrm{~mL})$ was added slowly the metal chloride $(0.475 \mathrm{mmol}, 5 \mathrm{~mL}$ EtOH $)$. The mixture was heated for several hours under dinitrogen and kept overnight at $4^{\circ} \mathrm{C}$. The complexes precipitated and were removed by filtration, washed several times with ethanol and diethyl ether (previously bubbled with dinitrogen for $15 \mathrm{~min}$ ). Finally, they were recrystallized from pyridine.

\section{Results and discussion}

\subsection{Molecular formula}

The analytical data of the new complexes are given in table 1. The complexes with both ligands showed pyridine (Pyr) associated to each of the complexes ( $\mathrm{Fe}(\mathrm{III}) \mathrm{ClL}^{n} \cdot \mathrm{Pyr}$, $\operatorname{Co}(\mathrm{II}) \mathrm{L}^{n} \cdot \operatorname{Pyr}(n=1$ or 2$)$ after recrystallization. All compounds were obtained with the

Table 1. Analytical data for the complexes.

\begin{tabular}{|c|c|c|c|c|c|c|}
\hline Compound & No. & Color & Yield $(\%)$ & Analysis C $(\%)$ & Calc. H $(\%)$ & (Found) N(\%) \\
\hline $\mathrm{Fe}(\mathrm{III}) \mathrm{ClL}^{1} \cdot \mathrm{Pyr}^{\mathrm{a}}$ & 1 & Brown & 53 & $\begin{array}{c}58.6 \\
(59.9)\end{array}$ & $\begin{array}{c}3.5 \\
(3.8)\end{array}$ & $\begin{array}{c}8.8 \\
(8.4)\end{array}$ \\
\hline $\mathrm{Fe}(\mathrm{III}) \mathrm{ClL}^{2} \cdot \mathrm{Pyr}$ & 2 & Brown & 60 & $\begin{array}{l}48.9 \\
(48.19)\end{array}$ & $\begin{array}{l}2.9 \\
(2.75)\end{array}$ & $\begin{array}{l}7.5 \\
(6.74)\end{array}$ \\
\hline $\mathrm{Co}(\mathrm{II}) \mathrm{L}^{1} \cdot \mathrm{Pyr}$ & 3 & Dark green & 47 & $\begin{array}{c}59.4 \\
(59.6)\end{array}$ & $\begin{array}{c}4.2 \\
(3.8)\end{array}$ & $\begin{array}{c}8.9 \\
(8.3)\end{array}$ \\
\hline $\mathrm{Co}(\mathrm{II}) \mathrm{L}^{2} \cdot \mathrm{Pyr}$ & 4 & Dark green & 56 & $\begin{array}{c}47.1 \\
(48.3)\end{array}$ & $\begin{array}{l}3.1 \\
(2.7)\end{array}$ & $\begin{array}{c}7.6 \\
(6.8)\end{array}$ \\
\hline
\end{tabular}

${ }^{\mathrm{a}} \mathrm{Pyr}=$ pyridine. 
Table 2. Spectroscopic data.

\begin{tabular}{|c|c|c|c|c|c|c|c|c|c|}
\hline \multirow{4}{*}{$\begin{array}{l}\text { Compound } \\
\mathrm{H}_{2} \mathrm{~L}^{1} \\
\mathrm{H}_{2} \mathrm{~L}^{2}\end{array}$} & \multicolumn{3}{|c|}{ Infrared $\left(\mathrm{cm}^{-1}\right)$} & & & & & & \\
\hline & \multirow{2}{*}{$\frac{v(\mathrm{O}-\mathrm{H})}{3398}$} & \multirow{2}{*}{$\begin{array}{c}v(\mathrm{C}=\mathrm{N}) \\
1610\end{array}$} & \multirow{2}{*}{$\frac{v(\mathrm{C}-\mathrm{O})}{1210}$} & \multicolumn{6}{|c|}{$\mathrm{UV}-\mathrm{Vis} \lambda(\mathrm{nm})[\varepsilon]\left(\mathrm{mol}^{-1} \mathrm{Lcm}^{-1}\right)$} \\
\hline & & & & 260 & [137100] & 332 & [116400] & & \\
\hline & 3414 & 1615 & 1270 & 266 & [166900] & 350 & [144500] & & \\
\hline 1 & 3455 & 1600 & 1300 & 240 & {$[11420]$} & 308 & [7490] & 388 & [3940] \\
\hline 2 & 3367 & 1600 & 1296 & 244 & [9330] & 310 & {$[8530]$} & 386 & [4560] \\
\hline 3 & 3433 & 1601 & 1217 & 260 & {$[48020]$} & 336 & [20180] & 428 & [1170] \\
\hline 4 & 3427 & 1598 & 1303 & 262 & [34036] & 360 & {$[12600]$} & 466 & [5550] \\
\hline
\end{tabular}

ligand dianion due to ionization of the two phenolic groups. The Co(II) complexes are neutral while $\mathrm{Fe}(\mathrm{III})$ species are cationic compounds with chloride as a counter ion. The molecular weight obtained by mass spectroscopy and the elemental analysis results are in good agreement with the proposed formulas.

\subsection{Mass spectrometry}

Positive ions corresponding to the different complexes $\left[\mathrm{M}^{+}\right]$were evidenced by MALDI-TOF using DMSO as solvent. The iron complexes showed strong ability to coordinate solvent molecules such as pyridine (recrystallization) or DMSO (spectrometry analysis). The molecular peak of $\mathrm{Fe}(\mathrm{III}) \mathrm{ClL}^{1} \cdot \mathrm{Pyr} .2 \mathrm{DMSO}$ was 619.83 corresponding to the loss of a hydrogen chloride molecule $\left(\mathrm{M}^{+}=\mathrm{M}-\mathrm{HCl}\right)$; $\mathrm{Fe}(\mathrm{III}) \mathrm{ClL}^{2} \cdot$ Pyr shows its molecular peak at $\mathrm{M}^{+}=656.85$ without DMSO molecules. For cobalt complexes, there were not detected molecules of solvent as for iron complexes, and the molecular peaks $(\mathrm{m} / \mathrm{z})$ are 389.03 and 544.85 for $\mathrm{CoL}^{1}$ and $\mathrm{CoL}^{2}$, respectively. These results can be used for molar weight confirmation. Complexes $\mathrm{Fe}(\mathrm{III}) \mathrm{ClL}^{1}$ and $\mathrm{Co}(\mathrm{II}) \mathrm{L}^{1}$ presented their expected molecular peaks, whereas dibrominated complexes (Fe(III) $\mathrm{ClL}^{2}$ and $\mathrm{Co}(\mathrm{II}) \mathrm{L}^{2}$ ) were accompanied with other peaks due to various isotopic combinations. Their relative abundances are typical of polyhalogenated compounds reported [34, 35].

\subsection{Infrared spectra}

The main vibration bands are given in table 2. A broad absorption was observed in the $3300-3650 \mathrm{~cm}^{-1}$ range in the ligand spectra (hydroxyl intra- and inter-molecular hydrogen bonding) and in the complexes, assigned to hydroxyl of the phenol. Comparison of the spectra of ligands with those of the complexes within the $1650-1178 \mathrm{~cm}^{-1}$ range indicates that the ligands coordinate through $\mathrm{N}$ and $\mathrm{O}$.

The $v(\mathrm{C}=\mathrm{N}), v(\mathrm{C}=\mathrm{C})$ and $v(\mathrm{C}-\mathrm{O})$ appear as very strong bands in the 1615-1602, $1460-1440$ and $1330-1178 \mathrm{~cm}^{-1}$ ranges, respectively. The band corresponding to the $\mathrm{C}=\mathrm{N}$ stretching vibration of the azomethine group is shifted to lower wavenumbers by 2 to $12 \mathrm{~cm}^{-1}$, while its intensity decreases [35-38], indicating coordination of the nitrogen to the metal center, leading to lower electron density on the azomethine. The $v(\mathrm{C}-\mathrm{O})$ shifts to higher wavenumbers as the electronegativity of the oxygen, exerting a withdrawing electron effect, leads to an increase of the $\mathrm{C}-\mathrm{O}$ bond electron density and strengthening of the force constant. These two facts are due to the 
coordination of the metal ion through: (i) oxygen of ionized hydroxyl and (ii) the nitrogens from imino [39, 40].

\subsection{Electronic spectra}

Electronic spectra (table 2) afford additional information about ligand coordination. For $\mathrm{H}_{2} \mathrm{~L}^{1}$ and $\mathrm{H}_{2} \mathrm{~L}^{2}$, a bathochromic effect is observed because of the presence of bromine in $\mathrm{H}_{2} \mathrm{~L}^{2}$. The molar absorption coefficient $\varepsilon$ is higher for $\mathrm{H}_{2} \mathrm{~L}^{2}$ because of extension of the conjugation reaching the d-electrons of bromine, leading to charge separation on the whole molecule. Electronic spectra of the free ligands in DMF showed two main absorption bands in the UV range $(260-350 \mathrm{~nm})$, attributed to the $\pi-\pi^{*}, n-\pi^{*}$ and $n-\sigma^{*}$ transitions [41]. Metal ions chelated by the ligands produce better charge transfer and the molar absorption coefficient $\varepsilon$ is greater (table 2). Thus, a bathochromic shift for $\mathrm{H}_{2} \mathrm{~L}^{1}$ was noted when passing from ligand to $\mathrm{Fe}(\mathrm{III}) \mathrm{ClL}^{1}$, also observed with all other complexes of this series. This is due to coordination bonds inducing electronic delocalization through the different $\mathrm{sp}^{2}$-hybridization systems in the molecule. New absorption bands in the UV-Vis region of $386-466 \mathrm{~nm}$ were assigned to $\mathrm{d}-\pi^{*}$ charge transfer transitions, which cause overlap with the $n-\pi^{*}$ and $n-\sigma^{*}$ transitions [41], leading to an important charge separation on the whole molecule. The metal ions bonded through two phenoxy groups $(\mathrm{OO})$ and two nitrogens $(\mathrm{NN})$ of the ligands produce a better charge transfer, and the molar absorption coefficient $\varepsilon$ is greater (table 2). The $\mathrm{d}-\mathrm{d}$ electronic transitions were not clearly observed in our electronic spectra [42, 43].

\section{Electrochemical properties of the ligands and complexes}

The cyclic voltammetry data of the complexes are summarized in table 3 and a representative cyclic voltammogram of $\mathrm{H}_{2} \mathrm{~L}^{2}$ under $\mathrm{N}_{2}$ atmosphere is given in Supplementary Material.

\subsection{Ligands}

The cyclic voltammetry of $\mathrm{H}_{2} \mathrm{~L}^{1}$ and $\mathrm{H}_{2} \mathrm{~L}^{2}$ was achieved in DMF solutions at various sweep rates in the -2000 to $+1400 \mathrm{mV}$ range. In the case of $\mathrm{H}_{2} \mathrm{~L}^{1}$, we observe three

Table 3. Cyclic voltammetry data under nitrogen.

\begin{tabular}{lrcccccc}
\hline Complex & $v\left(\mathrm{mV} \mathrm{s}^{-1}\right)$ & $-\mathrm{E}_{\mathrm{pa}}(\mathrm{mV})$ & $-\mathrm{E}_{\mathrm{pc}}(\mathrm{mV})$ & $-E_{1 / 2}(\mathrm{mV})$ & $\Delta E_{\mathrm{p}}(\mathrm{mV})$ & $i_{\mathrm{pa}} / i_{\mathrm{pc}}$ & $\mathrm{M}^{\mathrm{II} / \mathrm{III}}$ \\
\hline $\mathbf{1}$ & 100 & 80 & 180 & 130 & 100 & 1.00 & $\mathrm{r}$ \\
& 5 & 90 & 170 & 130 & 80 & 1.00 & \\
$\mathbf{2}$ & 100 & 140 & 220 & 180 & 80 & 0.86 & $\mathrm{qr}$ \\
& 5 & 130 & 210 & 170 & 80 & 0.53 & \\
$\mathbf{3}$ & 100 & 1100 & 1190 & 1145 & 90 & 0.66 & $\mathrm{qr}$ \\
& 5 & 1140 & 1200 & 1170 & 60 & 1.00 & \\
$\mathbf{4}$ & 100 & 440 & 720 & 580 & 280 & 0.62 & $\mathrm{qr}$ \\
& 5 & 600 & 700 & 650 & 100 & 1.00 & \\
\hline
\end{tabular}

r: reversible; qr: quasi-reversible. 
anodic waves, $E_{\mathrm{pa} 1}=240, E_{\mathrm{pa} 2}=960$ and $\mathrm{E}_{\mathrm{pa} 3}=1200 \mathrm{mV}$. Only $E_{\mathrm{pa} 1}$ shows its reduction wave, giving a redox system not well defined with the $E_{\mathrm{pa} 2}$ and $E_{\mathrm{pa} 3}$ not reversible. These irreversible anodic waves are attributed to the para- and ortho-oxidations of phenol moieties and of the phenol groups themselves [44-46]. During the back sweep, we observe two cathodic waves at $E_{\mathrm{pcl}}=+220$ and $\mathrm{E}_{\mathrm{pc} 2}=-1580 \mathrm{mV}$. However, the redox system observed at $\mathrm{E}_{1 / 2}=230 \mathrm{mV}$ is not well defined and the reduction wave appearing at $-1580 \mathrm{mV}$ may be assigned to the reduction of the ligand.

For $\mathrm{H}_{2} \mathrm{~L}^{2}$, the voltammogram was quite similar, with three anodic and two cathodic waves (Supplemental Material). In the anodic side, $E_{\mathrm{pa} 1}=+312, E_{\mathrm{pa} 2}=+930$ and $E_{\mathrm{pa} 3}=+1200 \mathrm{mV}$, whereas the cathodic waves appeared at $E_{\mathrm{pc} 1}=+250 \mathrm{mV}$ followed by $E_{\mathrm{pc} 2}=-1300 \mathrm{mV}$. In this case, the electron withdrawing due to the para-bromination of the phenol seems not significant for anodic waves, as expressed by the following $\quad \Delta E_{\mathrm{pa}} \quad$ differences: $\Delta E_{\mathrm{pa} 2}=E_{\mathrm{pa} 2}\left(\mathrm{H}_{2} \mathrm{~L}^{2}\right)-E_{\mathrm{pa} 2}\left(\mathrm{H}_{2} \mathrm{~L}^{1}\right)=30 \mathrm{mV} \quad$ and $\Delta E_{\mathrm{pa} 3}=E_{\mathrm{pa} 3}\left(\mathrm{H}_{2} \mathrm{~L}^{2}\right)-E_{\mathrm{pa} 3}\left(\mathrm{H}_{2} \mathrm{~L}^{1}\right)=0 \mathrm{mV}$, but this effect becomes very significant for the cathodic waves where we observe $E_{\mathrm{pc} 2}\left(\mathrm{H}_{2} \mathrm{~L}^{1}\right)$ and $E_{\mathrm{pc} 2}\left(\mathrm{H}_{2} \mathrm{~L}^{2}\right)$ at -1580 and $-1300 \mathrm{mV}$, respectively, with $\Delta E_{\mathrm{pc} 2}=E_{\mathrm{pc} 2}\left(\mathrm{H}_{2} \mathrm{~L}^{2}\right)-E_{\mathrm{pc} 2}\left(\mathrm{H}_{2} \mathrm{~L}^{1}\right)=+280 \mathrm{mV}$. These express the deficiency in electronic density in the ligand associated with an improvement of its reduction properties. These results are very close to those reported for similar compounds [16, 33, 47]. The different anodic and cathodic waves of the ligands and complexes were referenced in DMF solutions versus ferrocene. Under these conditions the ferrocenium/ferrocene couple was located at $E_{1 / 2}=+540 \mathrm{mV} / \mathrm{ECS}$ with peak to peak separation of $80 \mathrm{mV}$, as indicated in the literature [48].

\subsection{Complexes}

At anodic potentials, 1 shows four waves at $E_{\mathrm{pa} 1}=-500, E_{\mathrm{pa} 2}=-280, E_{\mathrm{pa} 3}=-120$ and $E_{\mathrm{pa} 4}=-1160 \mathrm{mV}$. The first is not assigned, while the second is the oxidation of $\mu$-dimer-oxo species [49]. The third represents oxidation of $\mathrm{Fe}(\mathrm{II})$ to $\mathrm{Fe}(\mathrm{III})$. The last wave is irreversible and may be attributed to oxidation of $\mathrm{Fe}$ (III) to $\mathrm{Fe}$ (IV) [50] or to the phenolic moieties as previously mentioned. For cathodic potentials, we observe successively three reduction waves at $E_{\mathrm{pc} 1}=+160 \mathrm{mV}, E_{\mathrm{pc} 2}=-180 \mathrm{mV}$ and $E_{\mathrm{pc} 3}=-1560 \mathrm{mV}$. The first is irreversible not assigned, and the second is the reduction of $\mathrm{Fe}(\mathrm{III})$ to $\mathrm{Fe}(\mathrm{II})$. The third is attributed to reduction of ligand.

The $\mathrm{E}_{1 / 2}$ values of the resulting redox system, attributed to $\mathrm{Fe}(\mathrm{III}) / \mathrm{Fe}(\mathrm{II})$, are almost invariable around $-130 \mathrm{mV}$, while the peak to peak potential separation $\Delta E \mathrm{p}$ is $\sim 100 \mathrm{mV}$ (at $100 \mathrm{mV} \mathrm{s}^{-1}$ ). These $\Delta E \mathrm{p}$ values decrease slightly $\left(80 \mathrm{mV}\right.$ for $5 \mathrm{mV} \mathrm{s}^{-1}$ ) and the current ratios $\left(i_{\mathrm{pa}} / i_{\mathrm{pc}}\right)$ are also invariable when increasing sweep rates; its value $\left(i_{\mathrm{pa}} / i_{\mathrm{pc}}=1.00\right)$ suggests a reversible redox system [51].

Iron complex 2 shows three oxidation waves: $E_{\mathrm{pa} 1}=-1420, E_{\mathrm{pa} 2}=-140$ and $E_{\mathrm{pa} 3}=+350 \mathrm{mV}$, respectively (Supplemental Material). The first wave may be due to oxidation of ligand and the second to oxidation of Fe(II) to Fe(III). The third may be attributed to reoxidation of $\mathrm{Fe}(\mathrm{III})$ to $\mathrm{Fe}(\mathrm{IV})$. During the back sweep, we also observe three cathodic waves appearing successively at $+30,-220$ and $-1520 \mathrm{mV}$. The three resulting redox systems were located at $E_{1 / 2}$ values: $-1470,-180$ and $+190 \mathrm{mV}$, respectively. In the case of $\mathrm{Fe}(\mathrm{II}) / \mathrm{Fe}(\mathrm{III})$, when the sweep rates increase, the cathodic potentials $E_{\mathrm{pc}}$ are slightly shifted to more cathodic potentials and 
$E_{1 / 2}$ values reach $-180 \mathrm{mV}$ while the $\Delta E_{\mathrm{p}}$ values remain stable at $80 \mathrm{mV}$. The changes in $i_{\mathrm{pc}}$ versus $v^{1 / 2}$ and the increase of $i_{\mathrm{pa}} / i_{\mathrm{pc}}$ ratio values with increasing sweep rate are typical of charge transfer associated with a kinetic process [51]. These results are in good agreement with a quasi-reversible redox system.

In contrast to $\mathbf{1}$, formation of $\mu$-dimer-oxo species from $\mathbf{2}$ was not observed (Supplemental Material), an advantage for applications in oxidation catalysis or electrocatalysis [15-17]. This behavior could arise from the presence of bromine. The electrochemical properties of these complexes are close to those already reported for the structures quite similar [47-49].

Complex 3 has three anodic waves, $E_{\mathrm{pa} 1}$ at $-1110, E_{\mathrm{pa} 2}$ at -240 and $E_{\mathrm{pa} 3}$ at $+1200 \mathrm{mV}$. The first wave is attributed to the $\mathrm{Co}$ (II) to $\mathrm{Co}$ (III) oxidation [7, 32]. The second is irreversible and not assigned, while the third is oxidation of the phenol as previously mentioned $[33,45]$. In the cathodic side, we observe three waves. The first at $E_{\mathrm{pcl}}=+800 \mathrm{mV}$ is not well defined and is probably due to reduction of the previously oxidized phenol. The second and third appearing at $E_{\mathrm{pc} 2}=-1190$ and at $E_{\mathrm{pc} 3}=-1840 \mathrm{mV}$ are due to successive reductions of $\mathrm{Co}(\mathrm{III})$ to $\mathrm{Co}(\mathrm{II})[7,32]$ and the ligand. However, values of the formal potentials taken as the mid-points of the anodic and cathodic peak potentials, for $\mathrm{Co}(\mathrm{III}) / \mathrm{Co}(\mathrm{II})$ couple at $\mathrm{E}_{1 / 2}=-1150 \mathrm{mV}$, is invariable at all sweep rates. The $\Delta E_{\mathrm{p}}$ values converge quickly to $90 \mathrm{mV}$ for higher scan rates while the current ratio $\left(i_{\mathrm{pa}} / i_{\mathrm{pc}}\right)$ decreases from unity with increasing sweep rates, suggesting a quasi-reversible system [51].

Cobalt complex 4, at anodic potentials, shows three oxidation waves at $E_{\mathrm{pa} 1}=-1400$, $E_{\mathrm{pa} 2}=-1100 \mathrm{mV}$ and $E_{\mathrm{pc} 3}=-440 \mathrm{mV}$. The first was not well defined and therefore not attributed. The second may be assigned to oxidation of $\mathrm{Co}$ (I) to $\mathrm{Co}$ (II) and the third to oxidation of $\mathrm{Co}$ (II) to $\mathrm{Co}$ (III) [32]. During the back sweep, three cathodic waves were observed at $E_{\mathrm{pc} 1}=-720, E_{\mathrm{pc} 2}=-1120$ and $E_{\mathrm{pc} 3}=-1500 \mathrm{mV}$. These reduction waves are attributed successively to the electroreduction of $\mathrm{Co}$ (III) to $\mathrm{Co}$ (II) and to $\mathrm{Co}(\mathrm{I})$ $[32,52]$ and the last is probably due to reduction of the ligand as mentioned previously. In this work, we are especially interested in the $\mathrm{Co}(\mathrm{III}) / \mathrm{Co}(\mathrm{II})$ redox system. Slight displacement of $E_{1 / 2}$ values to lower potentials was noted and an increase in the $\Delta E \mathrm{p}$ values was also observed (table 3 ) at higher sweep rates. On the other hand, the cathodic current $i_{\mathrm{pc}}$ increases with increasing scan rates and the ratio $i_{\mathrm{pa}} / i_{\mathrm{pc}}$ decreases from unity describing a charge transfer associated to a kinetic process [51]. This behavior is in agreement with a quasi-reversible redox system. For this redox system, the $i_{\mathrm{pc}}$ values increase faster than $i_{\mathrm{pa}}$ values when sweep rate is diminishing. In other words, the lowest values of $i_{\mathrm{pa}} / i_{\mathrm{pc}}$ ratio are obtained for low speeds and the highest value (1.0, see table 3 ) is obtained for highest speeds. This is due to partial oxygenation of $\mathrm{Co}(\mathrm{II})$ species. In fact, $\mathrm{Co}$ (II) complex species are known for their high reactivity towards oxygen, especially in the case of pentacoordinated complexes [7]. This electrochemical behavior is in agreement with that described for similar compounds by Khandar et al. [53].

Addition of ferrocene to these complexes reveals an enhancement of their cathodic peak current $i_{\mathrm{pc}}$ : 30\% 2, 20\% 3 and 50\% for $\mathbf{1}$ and 4 . This enhancement of the signal is not accompanied by a significant displacement of the $E_{1 / 2}$ values for the complexes; it will be possible to use ferrocene as an internal reference for electrochemical experiments and to obtain better sensors for the detection of these metals. 


\section{Electrocatalysis under dioxygen atmosphere}

\subsection{Under nitrogen atmosphere}

Cyclic voltammetry experiments were performed as described using DMF solutions of complex $\left(10^{-3} \mathrm{~mol} \mathrm{~L}^{-1}\right)$ 1-methylimidazole (Me-im; $\left.10^{-2} \mathrm{~mol} \mathrm{~L}^{-1}\right)$ and benzoic anhydride $\left(10^{-1} \mathrm{~mol} \mathrm{~L}^{-1}\right)$. The voltammograms were first recorded under nitrogen and then under oxygen at various sweep rates.

5.1.1. Complexes. The voltamperograms of $\mathbf{1}, \mathbf{2}, \mathbf{3}$ and $\mathbf{4}$ were recorded in the -2200 to $500 \mathrm{mV}$ range. The redox system of a given metal, appearing before dioxygen, may only be considered as a catalytic system if there is formation of oxygenated species. The $E_{1 / 2}$ value of $3(-1145 \mathrm{mV})$ is sufficiently far from reduction of molecular oxygen occurring around $-750 \mathrm{mV}$. In this case under dioxygen, the superoxyde species are exclusively produced as reported by Sawyer et al. [54]. For this reason, only 1, 2 and $\mathbf{4}$ (table 4: $E_{1 / 2}<-750 \mathrm{mV}$ ) may be considered as catalysts activating molecular oxygen like P450 cytochrome [55]. The voltammogram of 1 shows $\mathrm{Fe}(\mathrm{II}) / \mathrm{Fe}(\mathrm{III})$ redox couple located at $\mathrm{E}_{1 / 2}=-130 \mathrm{mV}$. This system is followed, for more cathodic potentials, by another redox system assigned to $\mu$-oxo dimer [Fe(III) $\left.\mathrm{L}^{1} \mathrm{Cl}\right]_{2} \mathrm{O}$ at $\mathrm{E}_{1 / 2}=-320 \mathrm{mV}$ [49]. These species are catalytically inactive towards oxidation reactions as previously described [56-58].

For 2 and 4, with the $p$-bromo substituted ligand $\mathrm{H}_{2} \mathrm{~L}^{2}$ giving a withdrawing effect, the $E_{1 / 2}$ values are shifted to more anodic potentials as expected, $-0.170 \mathrm{~V}$ (2) and $-0.650 \mathrm{~V}(\mathbf{4})$. The $\Delta E_{\mathrm{p}}$ values are stable around $80 \mathrm{mV}$ for $\mathbf{2}$ at any sweep rate, while those of 4 decrease from $280 \mathrm{mV}\left(100 \mathrm{mV} \mathrm{s}^{-1}\right)$ to $100 \mathrm{mV}\left(5 \mathrm{mV} \mathrm{s}^{-1}\right)$. For these two complexes, superoxo or $\mu$-oxo dimer are not observed though they were mentioned for similar compounds without halogen in their structure [59].

5.1.2. Complexes with 1-methylimidazole. The addition of $10^{-2} \mathrm{M}$ of nitrogen base like Me-im, acting as an axial ligand bound to the metal center, leads to a well-defined redox system without any significant displacement of $E_{1 / 2}$ values, showing a neat enhancement of the intensities of peak currents $\left(i_{\mathrm{pa}}, i_{\mathrm{pc}}\right)$. The nitrogen base coordinating to the central metal enhances the coordination number and produces an improvement of the electrophilic character of the metal center, and further reaction with molecular oxygen becomes easier. The first electron transfer on the metal center of $\mathbf{1}$ is given by equation (1):

$$
\mathrm{Fe}(\mathrm{III})+1 \mathrm{e}^{-} \rightleftharpoons \mathrm{Fe}(\mathrm{II})
$$

Thus, the $\mathrm{Fe}(\mathrm{II})$ or $\mathrm{Co}(\mathrm{II})$ species may develop important reactivity towards molecular oxygen as in cytochrome P450 [60].

\subsection{Under dioxygen}

5.2.1. Complexes without 1-methylimidazole. In this case, we observe a well-defined redox system for two complexes without significant displacement of anodic or cathodic peak potentials, but the cathodic peak currents $i_{\mathrm{pc}}$ decrease at low sweep rates. 
A. Ourari et al.

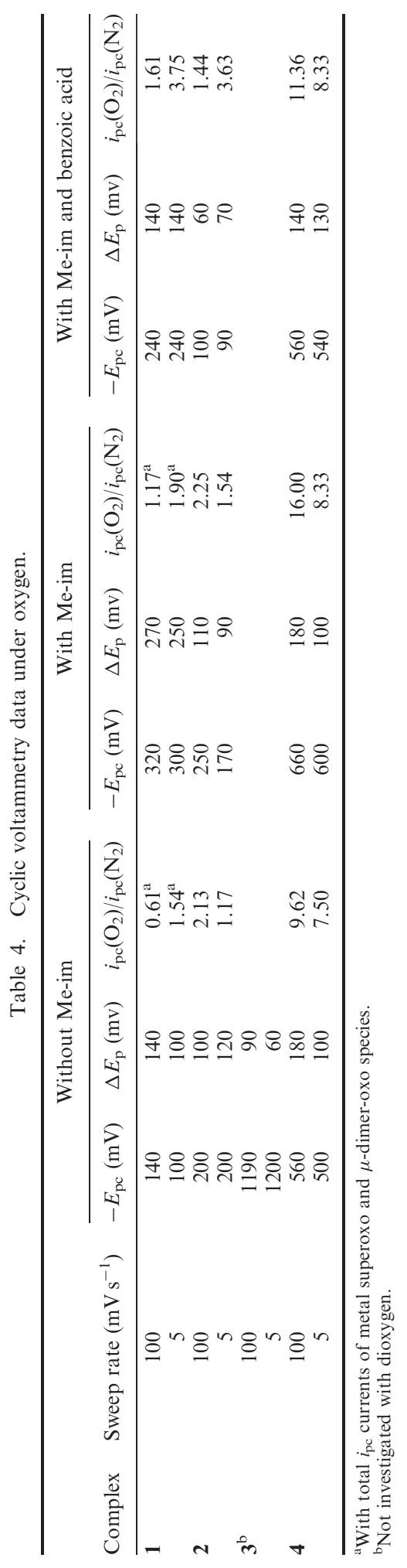


Thus, greater ratios for $i_{\mathrm{pc}}\left(\mathrm{O}_{2}\right) / i_{\mathrm{pc}}\left(\mathrm{N}_{2}\right)$ were obtained at $100 \mathrm{mV} \mathrm{s}^{-1}: 2.13$, and 9.62 for 2 and $\mathbf{4}$, respectively. This behavior is not observed with iron complex $\mathbf{1}$ because the greater ratio at lower scan rates $\left(5 \mathrm{mV} \mathrm{s}^{-1}\right)$ is 1.54 . Thus, it seems that brominated complexes 2 and 4 should exhibit better electrocatalytic activity, as reported [16, 17]. The best turnover was obtained for cyclooctene epoxidation to cyclooctene oxide using manganese complexes derived from 5,5'dichloro- [16] and 5,5'-dibromo-salen as catalysts [17].

5.2.2. Complexes with 1-methylimidazole. There is no shift of the redox system in the presence of molecular oxygen, comparable with reports by Murray et al. [58] for porphyrin structures. When adding Me-im, the speed of formation of the superoxo or peroxo species (peroxidase form) is increased as expressed by the ratios $i_{\mathrm{pc}}\left(\mathrm{O}_{2}\right) / i_{\mathrm{pc}}\left(\mathrm{N}_{2}\right)$ in table 4. This may arise from high basicity of 1-methylimidazole associated to its less hindrance [7]. However, molecular oxygen is reduced to hydrogen peroxide or water via a two- or four-electron transfer at chemically modified electrodes, as described by Murray [14], Anson [61] and Chang [62]. This process is illustrated in Supplemental Material and represented by equation (2):

$$
\mathrm{M}(\mathrm{II})+\mathrm{O}_{2} \rightleftharpoons \mathrm{M}(\mathrm{III})-\mathrm{O}-\mathrm{O}^{-}
$$

In these experimental conditions, the superoxo species are formed in large amounts for all complexes. This phenomenon is more important for $\mathbf{4}$ than for $\mathbf{1}$ and $\mathbf{2}$, giving a greater enhancement of the cathodic peak current, as expressed by the ratios $i_{\mathrm{pc}}\left(\mathrm{O}_{2}\right) / i_{\mathrm{pc}}\left(\mathrm{N}_{2}\right)=16.00(4)$ and only 2.25 (2) and $1.17(\mathbf{1})$. Without Me-im they were only 9.62 (4), 2.13 (2) and 0.61 (1), respectively. These results show that formation of a higher concentration of metal superoxo species is possible because the metal center becomes easily reactive towards dioxygen. A reproducible decrease of the ratios $i_{\mathrm{pc}}\left(\mathrm{O}_{2}\right) / i_{\mathrm{pc}}\left(\mathrm{N}_{2}\right)$ was also noted, indicating in presence or in absence of Me-im a high reactivity of these species (table 4). Thus, these oxygenated species are formed by EC [63] or ECE [15] mechanisms involving a mono- or bi-electron transfer associated with a reversible chemical reaction with molecular oxygen. These redox systems can easily be recovered by using nitrogen bubbling in the same solution for 20 to 30 minutes. The initial redox peaks are quite quantitatively recovered. This reversibility, in the solid state as well as in solution, has already been described [59, 64]. This electrochemical behavior is different for 1 due to its high reactivity towards dioxygen [48, 49] [equation (3)]; its redox couple is always accompanied, at more cathodic potentials, by a redox system of $\mu$-oxo dimer $\left[\mathrm{Fe}(\mathrm{III}) \mathrm{L}^{1} \mathrm{Cl}\right]_{2} \mathrm{O}$ (Supplemental Material). This behavior of $\mathbf{1}$ is a disadvantage for applications in oxidation electrocatalysis. Formation of this $\mu$-oxo dimer may be explained by equations (3-5) [49]:

$$
\begin{gathered}
2 \mathrm{Fe}(\mathrm{III}) \mathrm{CIL}^{1}+\frac{1}{2} \mathrm{O}_{2} \rightleftharpoons \mathrm{Fe}(\mathrm{III}) \mathrm{CIL}^{1}-\mathrm{O}-\mathrm{Fe}(\mathrm{III}) \mathrm{CIL}^{1} \\
{\left[\mathrm{Fe}(\mathrm{III}) \mathrm{ClL}^{1}\right]_{2} \mathrm{O}+\mathrm{e}^{-} \longrightarrow \mathrm{Fe}(\mathrm{III}) \mathrm{ClL}^{1}-\mathrm{O}-\mathrm{Fe}(\mathrm{II}) \mathrm{ClL}^{1}} \\
\mathrm{Fe}(\mathrm{III}) \mathrm{ClL}^{1}-\mathrm{O}-\mathrm{Fe}(\mathrm{II}) \mathrm{ClL}^{1} \longrightarrow \mathrm{Fe}(\mathrm{III}) \mathrm{ClL}^{1}-\mathrm{O}^{-}+\mathrm{Fe}\left(\mathrm{II}^{1} \mathrm{ClL}^{1}\right.
\end{gathered}
$$


Under dioxygen, 1 shows essentially, at $100 \mathrm{mV} \mathrm{s}^{-1}$, the $\mu$-oxo dimer but, at low scan rates, $\mathrm{Fe}(\mathrm{II}) \mathrm{ClL}^{1}$ is gradually recovered, according to equation 5 (also see Supplemental Material).

5.2.3. Complex with 1-methylimidazole and benzoic anhydride. Benzoic anhydride reacts with superoxo intermediates giving an oxo-compound with elimination of one oxygen [equation (6)] [14-17]:

$$
\mathrm{M}(\mathrm{III})-\mathrm{O}-\mathrm{O}^{-}+\left(\mathrm{C}_{6} \mathrm{H}_{5} \mathrm{CO}_{2}\right) \mathrm{O} \rightleftharpoons \mathrm{M}=\mathrm{O}+2 \mathrm{C}_{6} \mathrm{H}_{5} \mathrm{CO}_{2}
$$

In this case, when benzoic anhydride is added to the DMF solution containing complex and Me-im, the voltammograms show significant enhancement of the cathodic peak current $i_{\mathrm{pc}}$ and, a neat decrease of the anodic peak current, showing loss of reversibility of the redox system. This is due to consumption of the superoxo species transforming it into the corresponding metal-oxo species [equation (2)]. Upon this loss of reversibility, the electrophilic intermediates $\left(\mathrm{C}_{6} \mathrm{H}_{5}-\mathrm{CO}^{+}\right)$react faster with superoxo species [14-17]. Thus, the reactivity of the reduced state of $\mathrm{Fe}(\mathrm{II})$ and $\mathrm{Co}(\mathrm{II})$ species may be appreciated from the $i_{\mathrm{pc}}\left(\mathrm{O}_{2}\right) / i_{\mathrm{pc}}\left(\mathrm{N}_{2}\right)$ ratio values. In addition, we can note an important enhancement of the cathodic peak current $i_{\mathrm{pc}}\left(\mathrm{O}_{2}\right)$ explaining this phenomenon (Supplemental Material).

Metal-oxo species are formed at the same potentials as superoxo species. In addition, the metal-oxo species are electrochemically reduced at the same potential values of its formation, recovering quantitatively the initial form of the complex as previously reported [14-17]. The enhancement of the cathodic peak current $i_{\mathrm{pc}}\left(\mathrm{O}_{2}\right)$ expresses catalytic activity towards dioxygen and may be considered as an electrocatalytic current. It is given here by $i_{\mathrm{pc}}\left(\mathrm{O}_{2}\right) / i_{\mathrm{pc}}\left(\mathrm{N}_{2}\right)$. This phenomenon is also supported by curves of $i_{\mathrm{pc}}$ values versus the square root of sweep rates (figure 2). Their shapes are typical of a high electrocatalytic activity of these complexes towards dioxygen to produce metal oxo derivatives. These species allow further epoxidation of olefins or oxidation of hydrocarbons. Systematically high values of $i_{\mathrm{pc}}$, mainly in the presence of Me-im $\left(10^{-2} \mathrm{M}\right)$ and benzoic anhydride $\left(10^{-1} \mathrm{M}\right)$, indicate formation of metal-oxo species obtained from the superoxo ones (Supplementary Material). In these experimental conditions, the cathodic peak current ratios $i_{\mathrm{pc}}\left(\mathrm{O}_{2}\right) / i_{\mathrm{pc}}\left(\mathrm{N}_{2}\right)$ are $11.36(4), 1.44$ (2) and 1.61 (1) at $100 \mathrm{mVs}^{-1}(\mathbf{1})$, while at $5 \mathrm{mVs}^{-1}$ they are $8.33,3.63$ and 3.75 , respectively. Cobalt complex 4 should be the best catalytic system for oxidation reactions. Similar results have been reported for polyhalogenated porphyrin complexes [65].

\section{Conclusion}

Four new complexes were synthesized and characterized. These iron and cobalt complexes lead to unusual catalytic currents with intensities of cathodic current enhanced up to a 11.36 ratio. The ratios $i_{\mathrm{pc}}\left(\mathrm{O}_{2}\right) / i_{\mathrm{pc}}\left(\mathrm{N}_{2}\right)$ of the dibrominated 4 are almost stable and independent towards scan rate, in agreement with good stability for catalyst according to the literature $[16,17]$. Therefore, these complexes may be used as catalysts for epoxidation of olefins or oxidation of hydrocarbons using molecular oxygen. Moreover, these results may also be applied in building some new electrochemical 

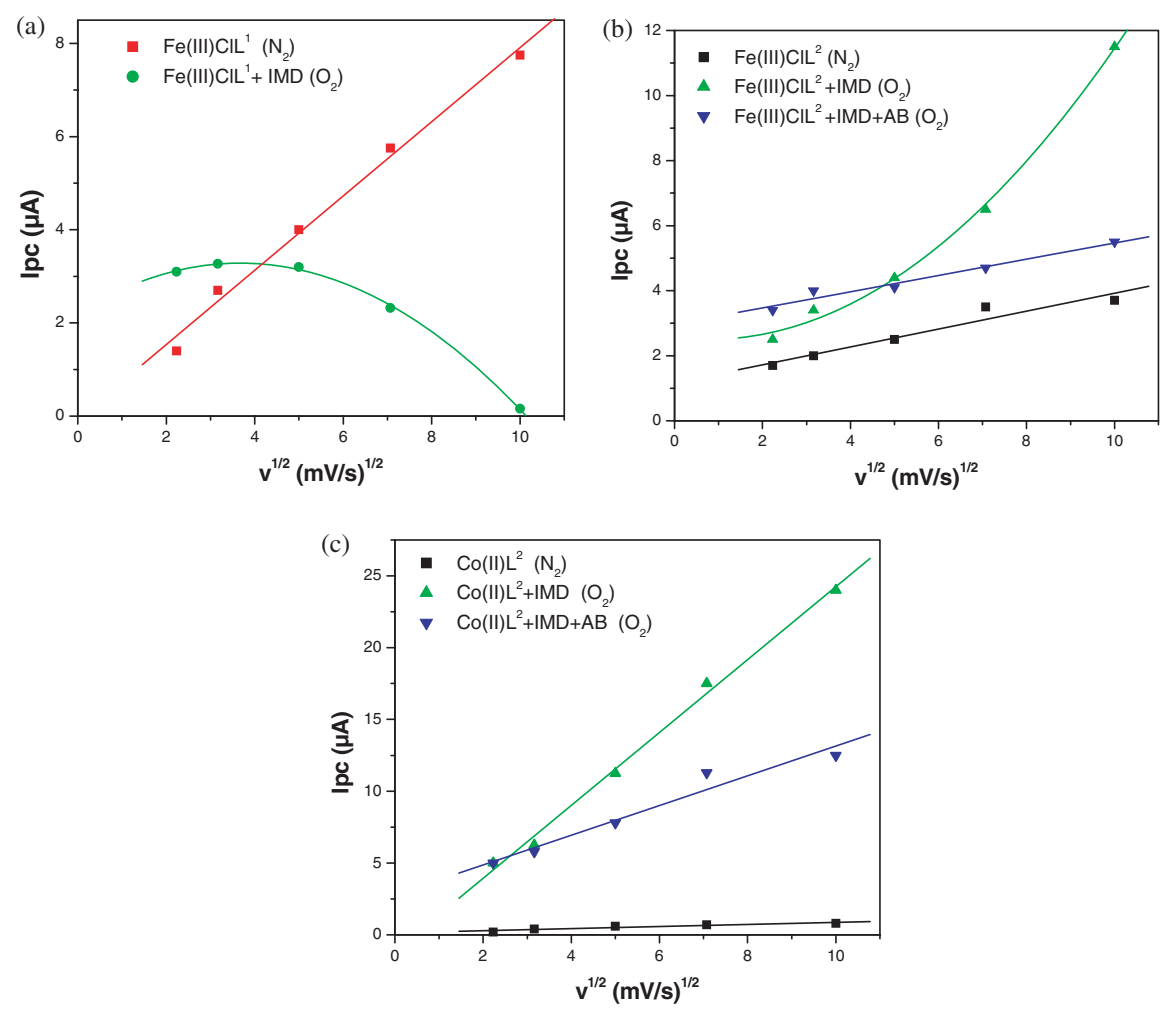

Figure 2. Plots of Ipc vs. $v^{1 / 2}$ (potential scan rate): $\mathrm{Fe}(\mathrm{III}) \mathrm{ClL}^{1}$ (a), $\mathrm{Fe}(\mathrm{III}) \mathrm{ClL}^{2}$ (b), and $\mathrm{Co}(\mathrm{II}) \mathrm{L}^{2}$ (c): ( $\mathbf{\square})$ under nitrogen atmosphere, and under oxygen atmosphere in the presence of: ( $\boldsymbol{\nabla})$ Me-im $10^{-2} \mathrm{M}$, (৫) Me-im $10^{-2} \mathrm{M}$ and benzoic anhydride $10^{-1} \mathrm{M}$.

devices as oxygen sensors with high sensitivity. There is significant enhancement of the $i_{\mathrm{pc}}$ current values in presence of catalytic amount of ferrocene and this could be useful for qualitative or quantitative analysis of these metals. This work is now in progress in our laboratory.

\section{Acknowledgements}

The authors want to acknowledge Professor Jean Weiss (Chimie des Ligands à Architecture Contrôlée, Laboratoire d'électrochimie, Institut Le Bel, Université Louis Pasteur, Strasbourg I, France) for helping in spectroscopic analyses.

\section{References}

[1] I.G. Denisov, T.M. Makris, S.G. Sligar, I. Schlichting. Chem. Rev., 105, 2253 (2005).

[2] I.C. Gunsalus, T.C. Pederson, S.G. Sligar. Annu. Rev. Biochem., 44, 377 (1975).

[3] T.G. Spiro. Metal Ion Activation of Dioxygen, Wiley, New York (1980). 
[4] Y.K. Choi, J.K. Park, S. Jeon. Electroanalysis, 11, 134 (1999).

[5] L. Gaillon, F. Bedioui. J. Mol. Catal. A, 214, 91 (2004).

[6] G.A. Ozin, C. Gil. Chem. Rev., 89, 1713 (1989).

[7] L. Salmon, C. Bied-Charreton, A. Gaudemer, P. Moisy, F. Bedioui, J. Devynck. Inorg. Chem., 29, 2734 (1990).

[8] L. Gaillon, N. Sajot, F. Bedioui, J. Devynck. J. Electroanal. Chem., 345, 157 (1993).

[9] S.E. Creager, S.A. Raybuk, R.W. Murray. J. Am. Chem. Soc., 108, 4225 (1986).

[10] H. Nashihara, K. Pressprich, R.W. Murray, J.P. Collman. Inorg. Chem., 29, 1000 (1990).

[11] D.M. Boughaei, S. Mohebi. Tetrahedron, 58, 5357 (2002).

[12] S. Mohebi, D.M. Boughaei, A. Servestani, A. Salimi. Appl. Catal. A, 278, 263 (2005).

[13] (a) R.M. Wang, C.J. Hao, Y.P. Wang, S.B. Li. J. Mol. Catal. A, 147, 173 (1999); (b) E. Kiatkowski, G. Romanowski, W. Nowicki, M. Kiatkowski, K. Suwinska. Polyhedron, 22, 1009 (2003).

[14] C.P. Horwitz, S.E. Creager, R.W. Murray. Inorg. Chem., 29, 1006 (1990).

[15] M.M. Taqui Khan, X.H. Mehta, A. Prakash Rao, K.N. Bhatt. J. Mol. Catal., 75, 245 (1992).

[16] J.C. Moutet, A. Ourari. Electrochim. Acta, 42, 2525 (1997).

[17] P. Guo, K.Y. Wong. Electrochem. Commun., 1, 559 (1999).

[18] F. Bedioui, E. De Boysson, J. Devynck, K.J. Balkus Jr. J. Chem. Soc., Faraday Trans., 87, 3831 (1991).

[19] S.F. Tan, P.-H. Leung, W.C. Sin. Transition Met. Chem., 16, 542 (1991).

[20] D.D. Agarwal, R.P. Bhatnagar, R. Jain, S. Srivastava. J. Mol. Catal., 59, 385 (1990).

[21] B.J. Ficher, R. Eisenberg. J. Am. Chem. Soc., 102, 7361 (1980).

[22] C.E. Dahm, D.G. Peters. Anal. Chem., 66, 3117 (1994).

[23] C.E. Dahm, D.G. Peters. J. Electroanal. Chem., 406, 119 (1996).

[24] G.N. Vyas, N.M. Shah. Org. Synth., Coll. Vol. IV, 886 (1963).

[25] (a) M. Yuasa, T. Nagaiwa, M. Kato, I. Sekine, S. Hayashi. J. Electrochem. Soc., 142, 2612 (1995); (b) I. Sasaki, D. Pujol, A. Gaudemer. Inorg. Chim. Acta, 134, 53 (1987).

[26] Y.W. Liou, C.M. Wang. J. Electroanal. Chem., 481, 102 (2000).

[27] J. Losada, I. del Peso, L. Beyer, J. Hartung, V. Fernandez, M. Möbius. J. Electroanal. Chem., 398, 89 (1995)

[28] P.N. Bartlett, J.M. Cooper. J. Electroanal. Chem., 362, 1 (1993).

[29] W. Schuhmann. Mikrochim. Acta, 121, 1 (1995).

[30] S. Cosnier, A. Le Pellec, B. Guidetti, I. Rico-Lattes. J. Electroanal. Chem., 449, 165 (1998).

[31] G. Cauquis, S. Cosnier, A. Deronzier, B. Galland, D. Limosin, J. Moutet, J. Bizot, D. Deprez, J.P. Pullicani. J. Electroanal. Chem., 352, 181 (1993).

[32] F. Bedioui, E. Labbe, S. Gutierrez-Granados, J. Devynck. J. Electroanal. Chem., 301, 267 (1991).

[33] A. Ourari, K. Ouari, W. Moumeni, L. Sibous, G. Bouet, M.A. Khan. Transition Met. Chem., 31, 169 (2006)

[34] (a) R.M. Silverstein, F.X. Webster. Spectrometric Identification of Organic Compounds, 6th Edn, John Wiley and Sons, New York (1999) pp. 34-35; (b) R. Droes, G. Nardin, L. Randaccio, P. Siega, G. Tauzher, V. Vrdojak. Inorg. Chim. Acta, 348, 239 (2003).

[35] J. Sanmartin, M.R. Bermejo, A.M. Garcia-Deibe, M. Maniero, C. Lage, A.J. Costa-Filho. Polyhedron, 19, 185 (2000).

[36] P. Gili, M.G. Martin-Reyes, P. Martin-Zarza, I.L.F. Machado, M.F.C. Guedes da Silva, M.A.N.D.A. Lemos, A.J.L. Pombiero. Inorg. Chim. Acta, 244, 25 (1996).

[37] L.J. Bellamy. The Infrared Spectra of Complex Molecules, 3rd Edn, Chapman and Hall, London (1975), p. 52.

[38] P. Gili, M.G. Martin-Reyes, P. Martin-Zarza, M.F.C. Guedes da Silva, Y.Y. Tong, A.J.L. Pombeiro. Inorg. Chim. Acta, 255, 279 (1996).

[39] A. Vogt, S. Wolowiec, R.L. Prasad, A. Gupta, J. Skarlewski. Polyhedron, 17, 1231 (1998).

[40] Z. Cimerman, N. Galic, B. Bosner. Anal. Chim. Acta, 343, 145 (1997).

[41] (a) A.B.P. Lever. Inorganic Electronic Spectroscopy, 2nd Edn, Elsevier, London (1992); (b) S. DjebarSaid, O. Benali-Baitich, J.P. Deloume. J. Mol. Struct., 569, 121 (2001).

[42] (a) W.M. Coleman, R.K. Boggess, J.W. Hughes, L.T. Taylor. Inorg. Chem., 20, 1253 (1981); (b) Z. Smekal, F. Brezina, Z. Sindelar, R. Klika. Polyhedron, 15, 1971 (1996).

[43] X.L. Zhang, W.J. Ruan, X.J. Zhao, H.J. Wang, Z.A. Zhu. Polyhedron, 22, 1534 (2003).

[44] (a) L. Papouchado, G. Petrie, J.H. Sharp, R.N. Adams. J. Am. Chem. Soc., 90, 5620 (1968); (b) U. Svanholm, K. Bechgaard, V.D. Parker. J. Am. Chem. Soc., 96, 2409 (1974).

[45] (a) G. Maki. J. Chem. Phys., 28, 651 (1958); (b) B. Speiser, A. Rieker. J. Chem. Res. (S), 314 (1977); (c) B. Speiser, A. Rieker. J. Electroanal. Chem., 102, 373 (1979).

[46] E.J. Land, G. Porter, E. Strachan. Trans. Faraday Soc., 1885 (1961).

[47] A. Pui, C. Policar, J.P. Mahy. Inorg. Chim. Acta, 360, 2139 (2007).

[48] D. Ranchet, J.B. Tommasino, O. Vittori, P.L. Fabre. J. Sol. Chem., 27, 979 (1998).

[49] J.P. Costes, J.B. Tommasino, B. Carre, F. Soulet, P.L. Fabre. Polyhedron, 14, 771 (1995).

[50] J.T. Groves, J.A. Gilbert. Inorg. Chim., 25, 125 (1986). 
[51] (a) R.S. Nicholson, I. Shain. Anal. Chem., 36, 706 (1964); (b) C. Evans, G.J. Harfoot, J.S. McIndoe, C.J. McAdam, K.M. Mackay, B.K. Nicholson, B.H. Robinson, M.L. Van Tiel. J. Chem. Soc., Dalton Trans., 4678 (2002).

[52] B. Costa, A. Puxeddu, E. Reisenhofer. J. Chem. Soc. Dalton, 1519 (1972).

[53] A.A. Khandar, B. Shaabani, F. Belaj, A. Bakhtiari. Inorg. Chim. Acta, 360, 3255 (2007).

[54] D.T. Sawyer, M.G. Gibia, M.M. Morrison, E.T. Seo. J. Am. Chem. Soc., 100, 627 (1978).

[55] S.E. Creager, R.W. Murray. Inorg. Chem., 26, 2612 (1987).

[56] I. Tabushi, M. Kodera, M. Yokoyama. J. Am. Chem. Soc., 107, 4466 (1985).

[57] F. Corazza, C. Floriani, M. Zehender. J. Chem. Soc., Dalton Trans., 709 (1987).

[58] (a) C. Floriani, F. Calderazzo. J. Chem. Soc; (A), 946 (1969); (b) R.H. Bailes, M. Calvin. J. Am. Chem. Soc., 69, 1886 (1947).

[59] (a) C. Floriani, F. Calderazzo. J. Chem. Soc. (A), 946 (1969); (b) A. Pui, I. Berdan, I. MorgensternBadarau, A. Gref, M. Pierrée-Fauvet. Inorg. Chim. Acta, 320, 167 (2001).

[60] P.K.S. Tsang, D.T. Sawyer. Inorg. Chem., 29, 2848 (1990).

[61] (a) J.P. Collman, M. Marroco, P. Denisevich, C. Koval, F.C. Anson. J. Electroanal. Chem., 101, 117 (1979); (b) J.P. Collman, P. Denisevich, Y. Konai, M. Marroco, F.C. Anson. J. Am. Chem. Soc., 102, 6027 (1980); (c) R.R. Durand, Jr, C.S. Benscosme, J.P. Collman, F.C. Anson. J. Am. Chem. Soc., 105, $2710(1983)$.

[62] (a) H.Y. Liu, I. Abdalmuhd, C.K. Chang, F.C. Anson. J. Phys. Chem., 89, 665 (1985); (b) H.Y. Liu, M.J. Weaver, C.B. Wang, C.K. Chang. J. Electroanal. Chem., 145, 439 (1983); (c) C.K. Chang, H.Y. Liu, I. Abdalmuhd. J. Am. Chem. Soc., 106, 2275 (1984).

[63] C.X. Cai, K.H. Xue, X.Y. Xu, Q.H. Luo. J. Appl. Electrochem., 27, 793 (1997).

[64] (a) J.H. Cameron, S.C. Turner. J. Chem. Soc., Dalton Trans., 3285 (1992); (b) T. Tsumaki. Bull. Chem. Soc. Jpn, 13, 252 (1938).

[65] (a) K.M. Kadish, C. Araull-McAdams, B.C. Han, M.M. Franzen. J. Am. Chem. Soc., 112, 8364 (1990); (b) T.G. Taylor, Y.S. Byun, P.S. Taylor, P. Battioni, D. Mansuy. J. Am. Chem. Soc., 113, 7821 (1991). 